\title{
Kinetic studies on the oxidation of diethylenetriaminepentaacetato chromium(III) by periodate
}

\author{
Zeinab M. Abou-Gamra*, Michel F. Abdel-Messih, Samy S. Anis, Eman H. Abdel-Khalek \\ Department of Chemistry, Faculty of Science, Ain shams University, Abbassia, Cairo, Egypt.
}

A RTICLE INFO

Article history:

Received 10 November 2013

Accepted 1 December 2013

Keywords:

Kinetics;

Oxidation;

Chromium (III)-DTPA.

\begin{abstract}
A B S T R A C T
The kinetics of the oxidation of diethylenetriaminepentaacetato chromium (III), (Cr(III)-DTPA), by periodate were studied spectrophotometrically over $\mathrm{pH}$ range 6.10-7.15 at $14-22^{\circ} \mathrm{C}$. The reaction follows first order with respect to $\mathrm{Cr}(\mathrm{III}) \mathrm{DTPA}$ and $\left[\mathrm{IO}_{4}{ }_{4}\right]$ and inversely dependent on $\left[\mathrm{H}^{+}\right]$. The mechanism involves the formation of an intermediate between the monohydroxochromium(III) complex and periodate which decomposes in rate determining step. The values of the intramolecular electron transfer, the formation constant of the intermediate and the hydrolysis constant of the complex were calculated. The activation parameters were calculated.
\end{abstract}

\section{Introduction}

Metal complexes which are relatively easily oxidized by periodate in aqueous solution, seem to classified (i) labile complexes ${ }^{[1,2]}$ and (ii) inert complexes that can offer bridge ligand ${ }^{[3,4]}$. The mechanism of oxidation of labile complexes is believed to be inner-sphere type, and direct evidence was supported this mechanism ${ }^{[1,2]}$. In case of oxidation of $\left[\mathrm{CrIII}(\mathrm{EDTA})\left(\mathrm{H}_{2} \mathrm{O}\right)\right]$ by periodate ${ }^{[2]}$, it was proposed that the oxidation was proceed via one or two electron transfer giving $\mathrm{Cr}(\mathrm{IV})$ or $\mathrm{Cr}(\mathrm{V})$, in the rate determining step followed by fast step leading to $\mathrm{Cr}(\mathrm{VI})$. The inner sphere process is also believed to be operating in oxidation of inert complexes ${ }^{[3,4]}$. Oxidation of chromium complexes by periodates showed a firstorder dependency on both the chromium complex and the oxidant ${ }^{[5-11]}$. The unusual second order dependence on $\left[\mathrm{Cr}\left(\mathrm{H}_{2} \mathrm{O}\right)_{6}\right]^{3+}$ in chromium periodate reaction seems to support an inner-sphere mechanism ${ }^{[4,12]}$. The two electron transfer step proposed for this mechanism where the hydroxyl form was considered to be the reactive chromium(III) species.

In this work, we report the extension of these studies to oxidize chromium(III)-DTPA complex by periodate ion. The conjugate base of DTPA has high affinity to form complexes with transition metals leaving the iminodiacetate group uncomplexed ${ }^{[13]}$. The difference in the course of the present study with that studied earlier was attributed to the difference in the anionic charge surrounding the central ion which plays an important role on the reaction rate. The experiments were carried out at different $\mathrm{pH}$ values and different

\footnotetext{
* Corresponding author.

E-mail address: zanibabougamra@yahoo.com
}

temperatures in order to promote differences as well as similarities in the redox process with that of aminopolyphosphonate complexes ${ }^{[7]}$. The effect on the precursor formation constant and the electron transfer rate constant has been studied.

\section{Materials and Methods}

$\mathrm{KIO}_{4}, \mathrm{Cr}\left(\mathrm{NO}_{3}\right)_{3} .9 \mathrm{H}_{2} \mathrm{O}, \mathrm{KNO}_{3}$ and DTPA were of pure grade and were used without further purification. The stock solution of chromium (III) was prepared and determined spectrophotometrically as chromate. The stock solution of DTPA was standardized by titration with $\mathrm{Zn}$ salt solution in hexamethylenetetraamine buffer $(\mathrm{pH}=6)$ with xylenol orange as an indicator. A solution of $\mathrm{Cr}(\mathrm{III}) \mathrm{DTPA}$ complex was prepared by leaving the mixture of $\mathrm{Cr}\left(\mathrm{NO}_{3}\right)_{3} \cdot 9 \mathrm{H}_{2} \mathrm{O}$ with a slight excess of DTPA concentration for $24 \mathrm{~h}$ at $\mathrm{pH}$ range 6.10-7.15. Spectrophotometric measurements were made to insure complete formation of the complex and the absence of uncomplexed chromium(III). The concentration of chromium(III) complex in the reaction was kept at 0.2 $\mathrm{mmol} \mathrm{dm}{ }^{-3}$.

\section{Kinetic measurements}

All kinetic measurements were carried out using a Unicam Helois $\alpha$ spectrophotometer equipped with a water-jacketed cell holder. The reactants were thermostated for $15 \mathrm{~min}$., then mixed thoroughly and quickly transferred to an absorption cell. The formation of chromium (VI) was followed by monitoring the absorbance at $\lambda_{\max }=370 \mathrm{~nm}$ as a function of time. Pseudo first-order conditions were maintained in all runs by using a large excess of periodate over the chromium(III) complex. The $\mathrm{pH}$ of the reaction was 
adjusted using buffer solution and measured using a radiometer $\mathrm{M} 62 \mathrm{pH}$-meter fitted with a combined glass calomel electrode. Measurements were recorded at an ionic strength of $0.2 \mathrm{~mol} \mathrm{dm}^{-3}$ using $\mathrm{KNO}_{3}$ solution.

\section{Results and discussion}

Addition of a colourless solution of potassium periodate to the chromium(III) DTPA complex results in disappearance of the peaks of the latter at $390 \mathrm{~nm}$ and $550 \mathrm{~nm}$, and formation of a yellow species, identified by its spectrum as chromium(VI) as shown in (Fig.1). Table 1 illustrates that under an experimental conditions $\mathrm{H}_{2}$ DTPA $^{3-}$ and $\mathrm{H}_{3}$ DTPA $^{2-}$ were found to be the dominant species ${ }^{[14]}$, whereas the hydroxo-species of chromium(III) ion, $\left[\mathrm{Cr}\left(\mathrm{H}_{2} \mathrm{O}\right)_{5} \mathrm{OH}\right]^{2+}$ was the dominant species for the chromium(III) ion therefore,

$\left[\mathrm{Cr}\left(\mathrm{H}_{2} \mathrm{O}\right)_{6}\right]^{3+} \stackrel{\mathrm{K}_{\mathrm{a}}}{\leftrightarrow}\left[\mathrm{Cr}\left(\mathrm{H}_{2} \mathrm{O}\right)_{5}(\mathrm{OH})\right]^{2+}+\mathrm{H}^{+}$

$\mathrm{K}_{\mathrm{a}}=1.3 \times 10^{-4} \mathrm{M}^{[15]}$

$\left.\left[\mathrm{Cr}\left(\mathrm{H}_{2} \mathrm{O}\right)_{5} \mathrm{OH}\right)\right]^{2+}+\left[\mathrm{H}_{3} \mathrm{DTPA}\right]^{2-} \rightarrow\left[\mathrm{CrH}_{3} \mathrm{DTPA}(\mathrm{OH})\right]$

$\left[\mathrm{Cr}\left(\mathrm{H}_{2} \mathrm{O}\right)_{5} \mathrm{OH}\right]^{2+}+\left[\mathrm{H}_{2} \mathrm{DTPA}\right]^{3-} \rightarrow\left[\mathrm{CrH}_{2} \mathrm{DTPA}(\mathrm{OH})\right]$

The inverse dependence of the reaction rate on the hydrogen ion concentration confirms that reactive species is $\left[\mathrm{Cr} \mathrm{H}_{2} \mathrm{DPTA}(\mathrm{OH})\right]^{-}$for the reduction of $\mathrm{IO}_{4}$ in which the complex is bridged to $\mathrm{IO}_{4}^{-}$through the hydroxo ligand. No reaction occurs between chromium (III) DTPA complex with $\mathrm{IO}_{3}^{-}$which indicates that $\mathrm{IO}_{3}{ }^{-}$is the final product for the present reaction. This is consistent with early reported ${ }^{[5-6,10-11]}$.

The oxidation kinetics of the chromium (III) complex by periodate was studied over $\mathrm{pH}$ range 6.10 to 7.15 over range of periodate and complex concentrations. The kinetics of the reaction was studied under pseudofirst order condition with the concentration of periodate greatly exceeding than that of the chromium (III) complex. The conventional plots of $\ln \left(\mathrm{A}_{\infty}-\mathrm{A}_{t}\right)$ versus time for at least three half -lives were found to be two linear stages with short reaction time and high rate constant followed by a second long reaction time with slower rate constant as shown in (Fig. 2). The observed rate constants $\mathrm{k}_{1 \mathrm{obs}}$ and $\mathrm{k}_{2 \mathrm{obs}}$ were calculated from the slopes of the first and second straight lines obtained respectively and are listed in Table 2 . The constancy of the observed rate constants $\left(\mathrm{k}_{1 \mathrm{obs}}\right.$ and $\left.\mathrm{k}_{2 \mathrm{obs}}\right)$ over the $\mathrm{Cr}(\mathrm{III})$ DTPA concentration $\left(1.8-2.4 \times 10^{-4} \mathrm{~mol} \mathrm{dm}^{-3}\right)$ is in agreement with a first order kinetics.

The first order plots which is consistent with only one reaction with two different rates is probably attributed to tendency of chromate anion to associate with DTPA complex thus competing with periodate ion for the available site on the chromium coordination sphere ${ }^{[16]}$. This suggestion is supported by the following:

1. The reaction did not proceed in the presence of iodate instead of periodate.

2. In the presence of hydrogen peroxide instead of periodate, the same behavior was observed where the plot of $\ln \left(\mathrm{A}_{\infty}-\mathrm{A}_{\mathrm{t}}\right)$ versus time leads to two linear stages, (Fig. 3), as observed in presence of periodate. Therefore the inflection shown in presence of periodate illustrates that iodate anion produced from the reduction of periodate does not compete the periodate ion for the available sites on the chromium (III) coordination sphere.

3. Linear parallel change between values of $\log \mathrm{k}_{1 \mathrm{obs}}$ and $\log \mathrm{k}_{2 \mathrm{obs}}$ versus the $\mathrm{pH}$ of the reaction, (Fig. 4), indicates a single reaction with rate constants characteristic to the slow and fast parts of the reaction.

4. Linear change of $\mathrm{k}_{1 \text { obs }}$ versus $\mathrm{k}_{2 \mathrm{obs}}$, (Fig. 5), also indicates single reaction with different rate constants.

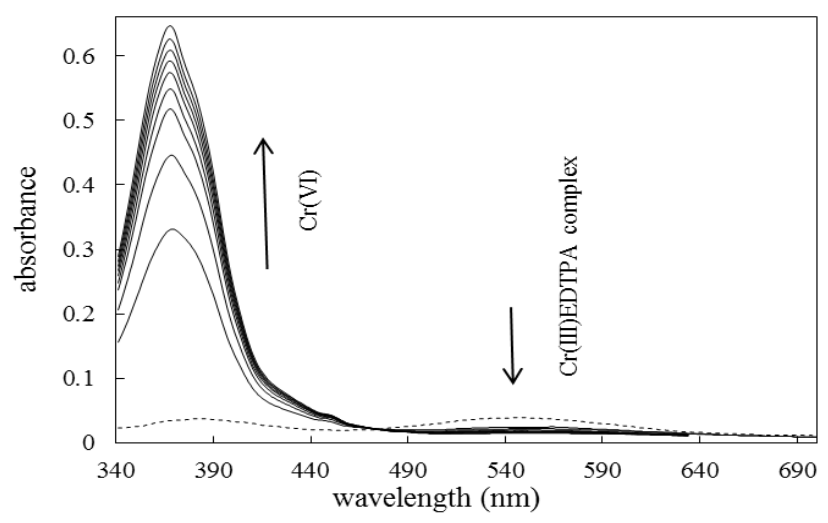

Fig. 1: Absorption spectrum of Cr(III)DTPA complex and periodate mixture at different time.

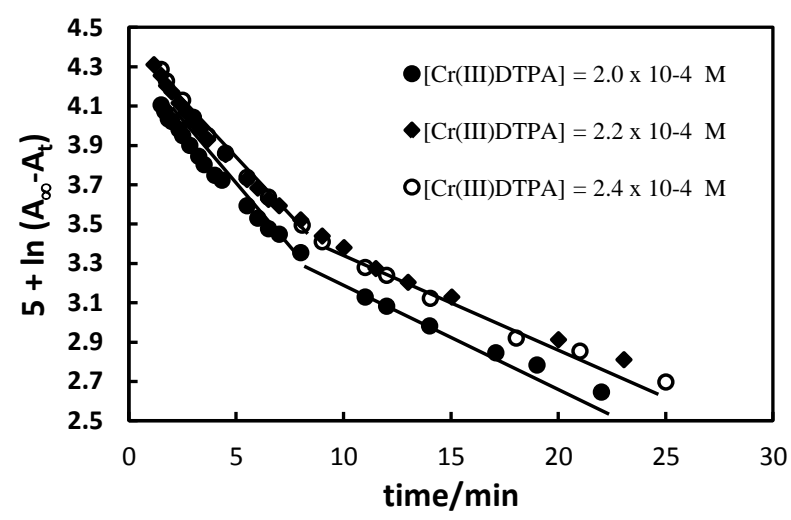

Fig. 2: Pseudo-first order plots of the reaction between $\mathrm{Cr}(\mathrm{III})$ DTPA complex and $\mathrm{KIO}_{4},\left[\mathrm{KIO}_{4}\right]=1.997 \times 10^{-3} \mathrm{~mol} \mathrm{dm}^{-3}$, Temp= $17^{\circ} \mathrm{C}, \mathrm{pH}=6.6$.

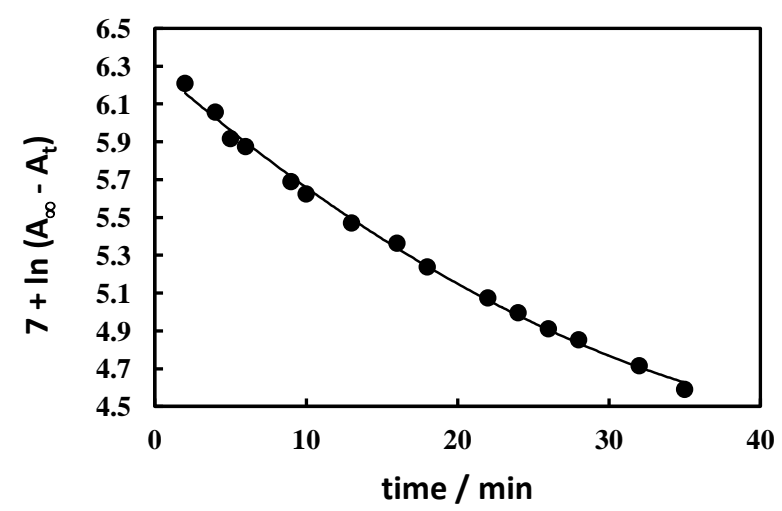

Fig. 3: Pseudo-first order plot of the reaction between Cr(III)-DTPA complex and $\mathrm{H}_{2} \mathrm{O}_{2}$, Temp $=42{ }^{\circ} \mathrm{C}$, [Cr(III)-DTPA $]=4 \times 10^{-4} \mathrm{~mol}$ $\mathrm{dm}^{-3},\left[\mathrm{H}_{2} \mathrm{O}_{2}\right]=3.67 \times 10^{-2} \mathrm{~mol} \mathrm{dm}{ }^{-3}$. 
Table 1: Acid protonation constants for $\mathrm{H}_{5} \mathrm{DTPA}^{[14]}$.

\begin{tabular}{lll}
$\log \mathrm{k}_{\mathrm{o} 11}=9.87$ & $\log \mathrm{k}_{\mathrm{o} 31}=4.2$ & $\log \mathrm{k}_{\mathrm{o} 51}=2.18$ \\
$\log \mathrm{k}_{\mathrm{o} 21}=8.64$ & $\log \mathrm{k}_{\mathrm{o} 41}=2.9$ & \\
\hline
\end{tabular}

Table 2: Kinetic data of oxidation of Cr(III) DTPA by $\mathrm{KIO}_{4}$.

\begin{tabular}{|c|c|c|c|c|c|}
\hline Complex x $10^{4} / \mathrm{mol} \mathrm{dm}^{-3}$ & $\mathrm{KIO}_{4} \times 10^{3} / \mathrm{mol} \mathrm{dm}^{-3}$ & Temp $/{ }^{0} \mathrm{C}$ & pH & $k_{10 b s} \times 10^{3} / s^{-1}$ & $k_{2 o b s} \times 10^{3} / s^{-1}$ \\
\hline \multirow[t]{5}{*}{2} & 1.997 & 14 & 6.1 & 0.529 & 0.244 \\
\hline & & & 6.3 & 0.785 & 0.335 \\
\hline & & & 6.5 & 1.107 & 0.450 \\
\hline & & & 6.7 & 1.642 & 0.635 \\
\hline & & & 6.9 & 2.360 & 1.011 \\
\hline \multirow[t]{5}{*}{2} & 1.997 & 17 & 6.2 & 0.883 & 0.339 \\
\hline & & & 6.4 & 1.243 & 0.487 \\
\hline & & & 6.6 & 1.438 & 0.725 \\
\hline & & & 6.8 & 2.859 & 1.219 \\
\hline & & & 7.0 & 3.810 & 1.644 \\
\hline \multirow[t]{5}{*}{2} & 1.997 & 22 & 6.2 & 1.001 & 0.467 \\
\hline & & & 6.4 & 1.285 & 0.670 \\
\hline & & & 6.7 & 3.282 & 1.368 \\
\hline & & & 7.0 & 5.213 & 2.263 \\
\hline & & & 7.15 & 6.460 & 2.689 \\
\hline \multirow[t]{4}{*}{2} & 1.614 & 17 & 6.4 & 1.073 & 0.431 \\
\hline & & & 6.6 & 1.492 & 0.622 \\
\hline & & & 6.8 & 2.134 & 0.997 \\
\hline & & & 7.0 & 3.148 & 1.314 \\
\hline \multirow[t]{6}{*}{2} & 1.997 & 17 & 6.2 & 0.883 & 0.339 \\
\hline & & & 6.4 & 1.243 & 0.487 \\
\hline & & & 6.6 & 1.438 & 0.725 \\
\hline & & & 6.8 & 2.859 & 1.219 \\
\hline & & & 7.0 & 3.810 & 1.644 \\
\hline & & 17 & & & \\
\hline \multirow[t]{6}{*}{2} & 2.300 & & 6.2 & 0.909 & 0.335 \\
\hline & & & 6.4 & 1.453 & 0.532 \\
\hline & & & 6.6 & 2.092 & 0.868 \\
\hline & & & 6.8 & 3.029 & 1.244 \\
\hline & & & 7.0 & 4.123 & 1.741 \\
\hline & & 17 & & & \\
\hline \multirow[t]{4}{*}{2} & 2.774 & & 6.2 & 0.995 & 0.367 \\
\hline & & & 6.4 & 1.507 & 0.553 \\
\hline & & & 6.6 & 2.174 & 0.903 \\
\hline & & & 6.7 & 2.899 & 1.408 \\
\hline \multirow[t]{4}{*}{2} & 3.026 & 17 & 6.2 & 1.146 & 0.447 \\
\hline & & & 6.4 & 1.665 & 0.722 \\
\hline & & & 6.7 & 3.070 & 1.325 \\
\hline & & & 6.8 & 4.024 & 1.652 \\
\hline 1.8 & 1.997 & 17 & 6.4 & 1.153 & 0.425 \\
\hline 2.0 & & & & 1.243 & 0.487 \\
\hline 2.2 & & & & 1.385 & 0.510 \\
\hline 2.4 & & & & 1.409 & 0.537 \\
\hline 1.8 & 1.997 & 17 & 6.6 & 1.802 & 0.691 \\
\hline 2.0 & & & & 1.938 & 0.725 \\
\hline 2.2 & & & & 2.132 & 0.965 \\
\hline 2.4 & & & & 2.396 & 1.023 \\
\hline
\end{tabular}


Table 3: Summary of kinetic data and activation parameters for the oxidation of chromium (III) DTPA by periodate.

\begin{tabular}{lllll}
\hline & \multicolumn{2}{c}{ First part } & \multicolumn{2}{c}{ Second part } \\
$\mathbf{p H}$ & $\mathbf{k} / \mathbf{s}^{-\mathbf{1}}$ & $\mathbf{K}_{\mathbf{2}} / \mathbf{m o l}^{-1} \mathbf{d m}^{\mathbf{3}}$ & $\mathbf{k ~ s}^{-\mathbf{1}}$ & $\mathbf{K}_{\mathbf{2}} / \mathbf{m o l}^{-\mathbf{1}} \mathbf{d m}^{\mathbf{3}}$ \\
\hline 6.2 & $2.771 \times 10^{-3}$ & $0.516 \times 10^{3}$ & $0.59 \times 10^{-3}$ & $1.347 \times 10^{3}$ \\
6.4 & $4.002 \times 10^{-3}$ & $0.4103 \times 10^{3}$ & $1.03 \times 10^{-3}$ & $0.814 \times 10^{3}$ \\
6.6 & $17.37 \times 10^{-3}$ & $0.090 \times 10^{3}$ & $2.15 \times 10^{-3}$ & $0.452 \times 10^{3}$ \\
& $\Delta \mathrm{H}^{*}=50.63 \mathrm{~kJ} \mathrm{~mol}^{-1}$ & $\Delta \mathrm{H}^{*}=70 \mathrm{~kJ} \mathrm{~mol}^{-1}$ \\
& $\Delta \mathrm{S}^{*}=-76.7 \mathrm{~J} \mathrm{~K}^{-1} \mathrm{~mol}^{-1}$ & $\Delta \mathrm{S}^{*}=-16.6 \mathrm{~J} \mathrm{~K}^{-1} \mathrm{~mol}^{-1}$ \\
\hline
\end{tabular}

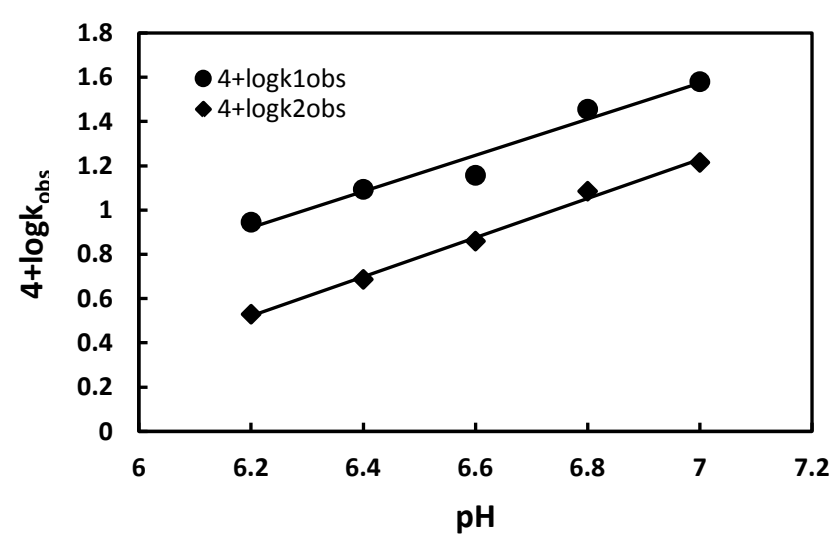

Fig. 4: Variation of $\log \mathrm{k}_{1 \mathrm{obs}}$ and $\log \mathrm{k}_{2 \mathrm{obs}}$ with $\mathrm{pH}$, [Cr(III)-DTPA] $=2 \times 10^{-4} \mathrm{~mol} \mathrm{dm}^{-3},\left[\mathrm{KIO}_{4}\right]=1.997 \times 10^{-3} \mathrm{~mol} \mathrm{dm}^{-3}$ and Temp $=$ $17^{\circ} \mathrm{C}$.
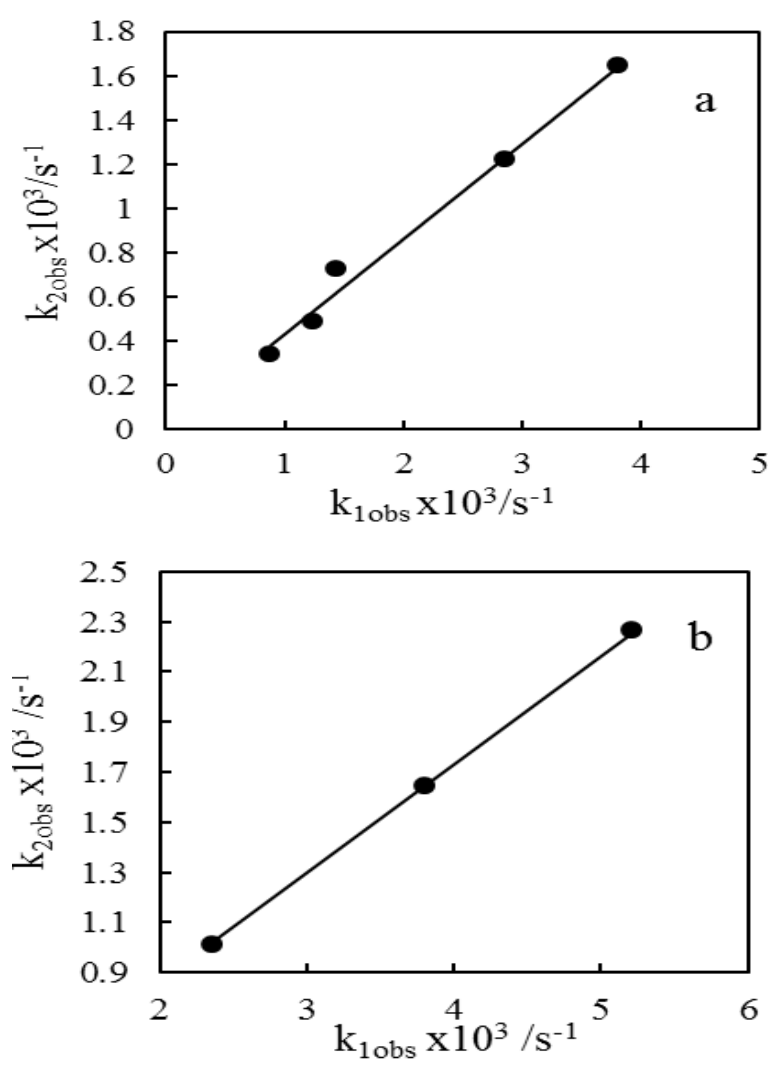

Fig. 5: Variation of $\mathrm{k}_{1 \text { obs }}$ with $\mathrm{k}_{2 \mathrm{obs}}[\mathrm{Cr}(\mathrm{III})-\mathrm{DTPA}]=2 \times 10^{-4} \mathrm{~mol}$ $\mathrm{dm}^{-3},\left[\mathrm{KIO}_{4}\right]=1.997 \times 10^{-3} \mathrm{~mol} \mathrm{dm}^{-3}, \mathrm{a}-\mathrm{Temp} .=17^{\circ} \mathrm{C}$ and different $\mathrm{pH}, \mathrm{b}-\mathrm{pH}=7$ and different temp.
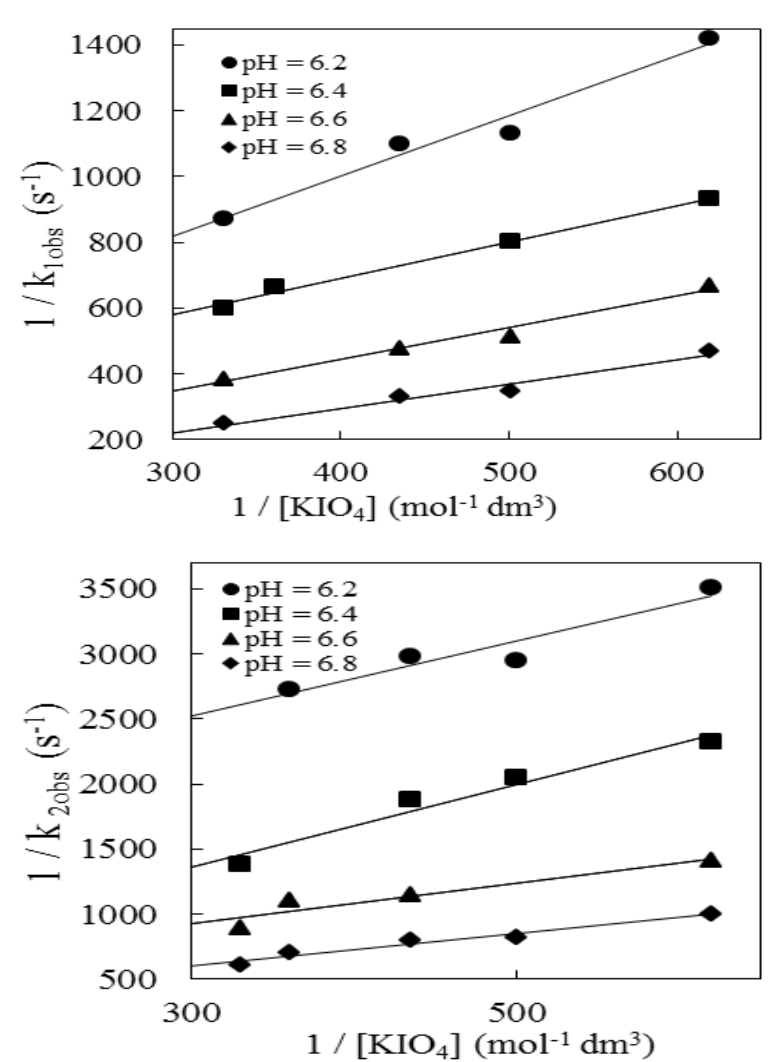

Fig. 6: The variation of $1 / \mathrm{k}_{1 \text { obs }}$ and $1 / \mathrm{k}_{2 \mathrm{obs}}$ with $1 /\left[\mathrm{KIO}_{4}\right]$ at various $\mathrm{pH}$ values. Temp $=17{ }^{\circ} \mathrm{C},[\mathrm{Cr}(\mathrm{III})-\mathrm{DTPA}]=2 \times 10^{-4} \mathrm{~mol} \mathrm{dm}^{-3}$.

When all experimental conditions were kept constant except the periodate concentration, the observed first order rate constant is directly proportional to the concentration of periodate and a linear relationship was obtained when observed rate constant was plotted versus periodate concentration reaching a limiting value of high periodate concentration. The variation $\mathrm{k}_{\mathrm{obs}}$ with $\left[\mathrm{IO}_{4}^{-}\right]$ are small indicating high association between the two reactants. A Michealis-Menten plot with respect to periodate concentrations resulted in linear relationship with non-zero intercept by plotting of $\mathrm{k}_{\mathrm{obs}}{ }^{-1}$ versus $1 /\left[\mathrm{IO}_{4}{ }^{-}\right]$(Fig. 6).

The dependence of the observed rate constants on the $\mathrm{pH}$ of the medium is presented in (Fig. 7), where straight lines measurable intercepts were obtained when $\mathrm{k}_{\mathrm{obs}}{ }^{-1}$ values were plotted versus $\left[\mathrm{H}^{+}\right]$at different temperatures. A mechanism consistent with the observed kinetics is 
$\left[\mathrm{CrH}_{2} \operatorname{DTAP}\left(\mathrm{H}_{2} \mathrm{O}\right)\right] \stackrel{\mathrm{K}_{1}}{\leftrightarrow}\left[\mathrm{CrH}_{2} \mathrm{DTPOH}\right]^{-}+\mathrm{H}^{+}$

$\left[\mathrm{CrH}_{2} \mathrm{DTPOH}\right]^{-}+\mathrm{IO}_{4}^{-} \stackrel{\mathrm{K}_{2}}{\leftrightarrow}\left[\mathrm{CrH}_{2} \mathrm{DTPOHIO}_{4}\right]^{2-}$

$\left[\mathrm{Cr} \mathrm{H}_{2} \text { DTPA }(\mathrm{OH}) \mathrm{IO}_{4}\right]^{2-} \stackrel{\mathrm{K}}{\rightarrow} \mathrm{Cr}^{\mathrm{VI}}+\mathrm{IO}_{3}^{-}+\mathrm{H}_{2} \mathrm{DTPA}^{3-}$

An inner sphere mechanism is proposed for oxidation of the $\mathrm{Cr}$ (III)DTPA complex with periodate, in which the hydroxo complex is the bridged to periodate (scheme 1).<smiles>O=C1OOO[CH]C1[18OH]</smiles>

(Scheme 1)

This proposal is supported by the inverse dependence of the rate on the hydrogen ion concentration. Therefore the periodate replaces the hydroxyl group and the substitution takes place in the two stages;

$\left[\mathrm{CrH}_{2} \mathrm{DTPA}(\mathrm{OH})\right]^{-} \leftrightarrow\left[\mathrm{CrH}_{2} \mathrm{DTPA}\right]+\mathrm{OH}^{-}$

$\left[\mathrm{Cr} \mathrm{H}_{2}\right.$ DTPA $]+\mathrm{IO}_{4}^{-} \rightarrow\left[\mathrm{Cr} \mathrm{H}_{2} \text { DTPA. } \mathrm{IO}_{4}\right]^{-}$

The labilizing effect of the free carboxylate of the Cr(III) DTPA complex, (scheme 2), through its inductive effect reflects the easy rupture of $\mathrm{Cr}-\mathrm{OH}$ bond and facilitate the insertion of periodate in the coordination sphere of chromium (III). Ogino et al ${ }^{\text {[17] }}$ showed that with the quinquedentate Cr-EDTA complex there is a rapid equilibration with acetate ligand (replacement of a coordinated $\mathrm{H}_{2} \mathrm{O}$ by $\mathrm{CH}_{3} \mathrm{COO}^{-}$anion), whereas with the structurally related quinquedentate $\mathrm{Cr}$ MEDTA (META is N-methyl-ethyl-NN`N`-triacetic acid), the methyl group is unable to labilise the coordinated water molecule. The labilisation effect of the carboxylate was attributed to a transient six dentate coordination of EDTA ${ }^{[16]}$. This suggests that bond breaking and bond formation processes are taking place through a common entering $\mathrm{IO}_{4}^{-}$and leaving coordinated $\mathrm{OH}^{-}$.
From the above mechanism, the rate of reaction can be represented as follows:

rate $=\mathrm{k}\left[\mathrm{Cr} \mathrm{H}_{2} \mathrm{DTPA}(\mathrm{OH}) \cdot \mathrm{IO}_{4}{ }^{2-}\right]$

$$
=\mathrm{kK}_{2}\left[\mathrm{Cr} \mathrm{H}_{2} \mathrm{DTPA}(\mathrm{OH})^{-}\right]\left[\mathrm{IO}_{4}^{-}\right]
$$

If $[\mathrm{Cr}(\mathrm{III})]_{\mathrm{T}}$ represents the total concentration of $\mathrm{Cr}(\mathrm{III})$ species, then:

$[\mathrm{Cr}(\mathrm{III})]_{\mathrm{T}}=\left[\mathrm{CrH}_{2} \mathrm{DTPA}(\mathrm{OH})^{-}\right]+\left[\mathrm{Cr} \mathrm{H}_{2} \mathrm{DTPA}\left(\mathrm{H}_{2} \mathrm{O}\right)\right]+[\mathrm{Cr}$ $\left.\mathrm{H}_{2} \mathrm{DTPA}(\mathrm{OH}) \cdot \mathrm{IO}_{4}^{2-}\right]$

$$
\begin{aligned}
& =\left[\mathrm{CrH}_{2} \mathrm{DTP}(\mathrm{OH})^{-}\right]+\left\{\frac{\left[\mathrm{CrH}_{2} \mathrm{DTP}(\mathrm{OH})^{-}\right]\left[\mathrm{H}^{+}\right]}{\mathrm{K}_{1}}\right\} \\
& +\mathrm{K}_{2}\left[\mathrm{CrH}_{2} \mathrm{DTP}(\mathrm{OH})^{-}\right]\left[\mathrm{IO}_{4}^{-}\right] \\
& {[\mathrm{Cr}(\mathrm{III})]_{\mathrm{T}}=\left[\mathrm{CrH}_{2} \mathrm{DTP}(\mathrm{OH})^{-}\right]\left\{1+\frac{\left[\mathrm{H}^{+}\right]}{\mathrm{K}_{1}}+\mathrm{K}_{2} \mathrm{IO}_{4}^{-}\right\}} \\
& =\left[\mathrm{CrH}_{2} \mathrm{DTPA}(\mathrm{OH})^{-}\right]\left\{\frac{\mathrm{K}_{1}+\left[\mathrm{H}^{+}\right]+\mathrm{K}_{1} \mathrm{~K}_{2}\left[\mathrm{IO}_{4}^{-}\right]}{\mathrm{K}_{1}}\right\} \\
& \therefore \text { rate }=\frac{\left.\mathrm{kK}_{1} \mathrm{~K}_{2}[\mathrm{CrIII})\right]_{\mathrm{T}}\left[\mathrm{IO}_{4}^{-}\right]}{\mathrm{K}_{1}+\left[\mathrm{H}^{+}\right]+\mathrm{K}_{2} \mathrm{~K}_{1}\left[\mathrm{IO}_{4}^{-}\right]} \\
& \mathrm{k}_{\mathrm{obs}}=\frac{\mathrm{kK}_{1} \mathrm{~K}_{2}\left[\mathrm{IO}_{4}^{-}\right]}{\mathrm{K}_{1}+\left[\mathrm{H}^{+}\right]+\mathrm{K}_{1} \mathrm{~K}_{2}\left[\mathrm{IO}_{4}^{-}\right]}
\end{aligned}
$$

Equation (13) can be rearranged to give:

$$
\frac{1}{\mathrm{k}_{\mathrm{obs}}}=\frac{\mathrm{K}_{1}+\left[\mathrm{H}^{+}\right]}{\mathrm{kK}_{2} \mathrm{~K}_{1}\left[\mathrm{IO}_{4}^{-}\right]}+\frac{1}{\mathrm{k}}
$$

From (eq. 14) and (Fig. 6), it follows that the slopes of the plots can be represented by:

slope $=\frac{\mathrm{K}_{1}+\left[\mathrm{H}^{+}\right]}{\mathrm{kK}_{2} \mathrm{~K}_{1}}=\frac{1}{\mathrm{kK}_{2}}+\frac{\left[\mathrm{H}^{+}\right]}{\mathrm{kK}_{2} \mathrm{~K}_{1}}$

It is obvious, from (eq. 15) and (Fig. 6) that the slope is dependent upon $\left[\mathrm{H}^{+}\right]$.

This plot is shown in (Fig. 8) which indicates the validity of the proposed mechanism. The $\mathrm{K}_{1}$ value was calculated from (eq. 15) and (Fig. 8) as $\mathrm{pK}_{1}=6.31$. The rate constant for the intramolecular electron transfer, $\mathrm{k}$, and the equilibrium constant for the formation of the activated complex $\mathrm{K}_{2}$, at different $\mathrm{pH}$ values are listed in Table 3, together with the $\Delta \mathrm{H}^{*}$ and $\Delta \mathrm{S}^{*}$ values. Table 3 illustrates that $\mathrm{K}_{2}$ ( eq.5) decreases as the $\mathrm{pH}$ increases, due to the increase of chromate ions concentration with

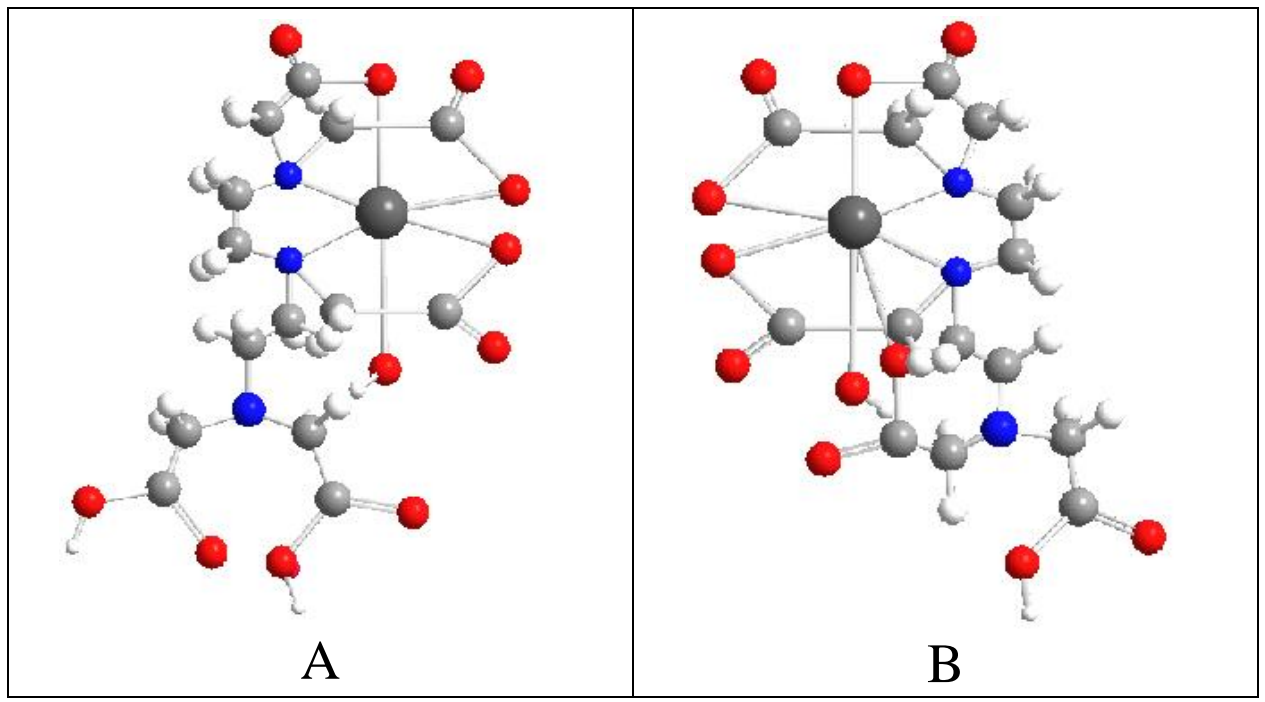

(Scheme 2): A- Cr-DTPA complex, B- transient Cr-DTPA complex 
increasing $\mathrm{pH}$ value $\left(\mathrm{k}_{\mathrm{obs}}\right.$ is directly proportional to $\left.\mathrm{pH}\right)$. This is supported that chromate ions are responsible for the inflection of straight line. Linear isokinetics plot for oxidation of hydroxochromium(III) complexes by periodate, (Fig. 9) indicates that they follow the same mechanism.
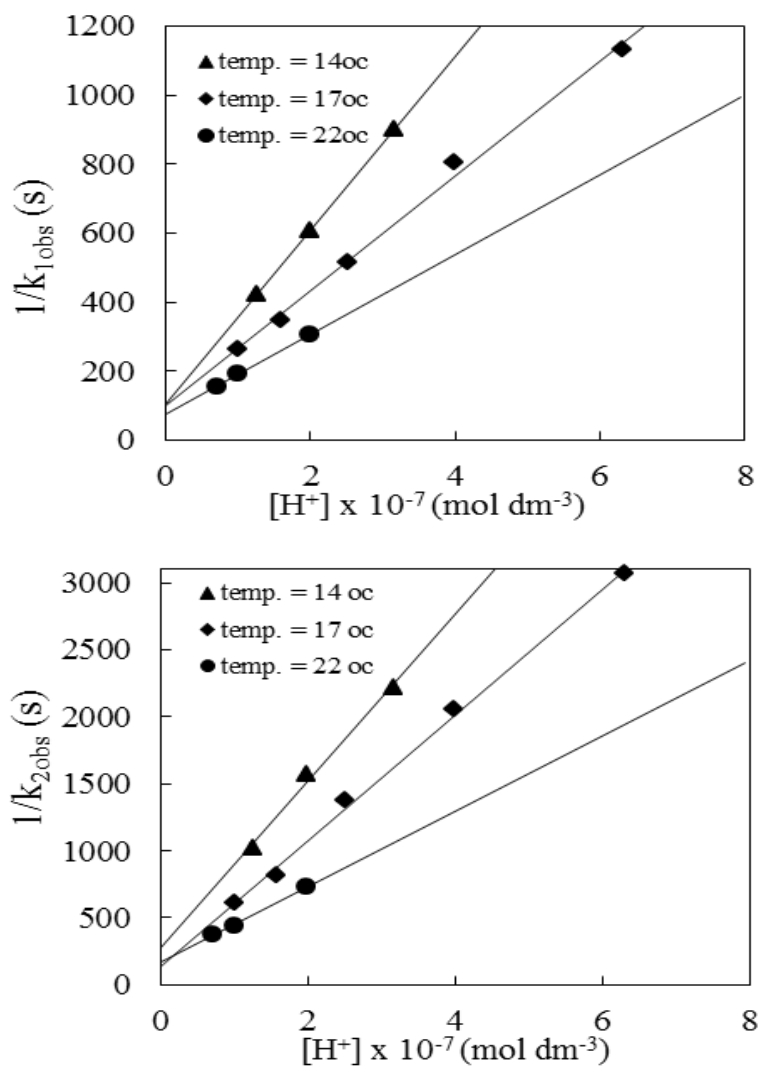

Fig. 7: The inverse dependence of $k_{1 \text { obs }}$ and $k_{2 o b s}$ on the concentration of the hydrogen ion at various temperature, $\left[\mathrm{KIO}_{4}\right]=$ $1.997 \times 10^{-3} \mathrm{~mol} \mathrm{dm}^{-3},[\mathrm{Cr}(\mathrm{III})-\mathrm{DTPA}]=2 \times 10^{-4} \mathrm{~mol} \mathrm{dm}^{-3}$.

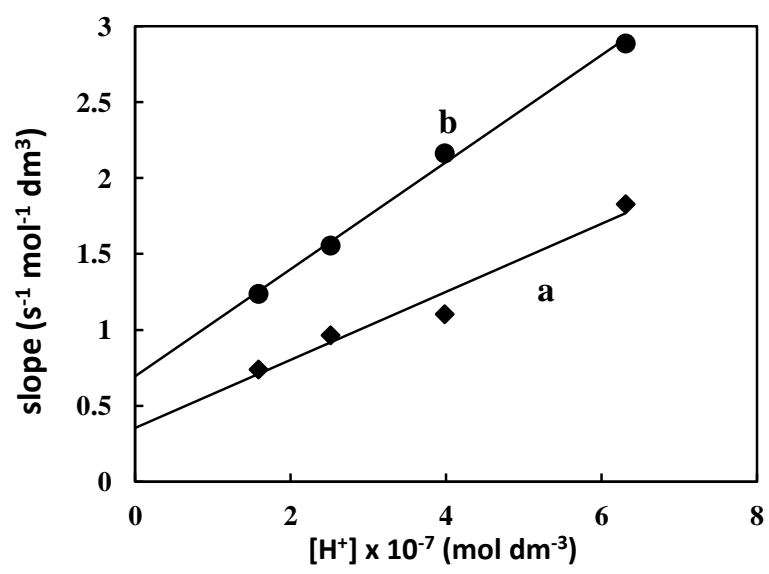

Fig. 8: Plot of $1 / \mathrm{kK}_{2}+\left[\mathrm{H}^{+}\right] / \mathrm{kK}_{1} \mathrm{~K}_{2}$ versus hydrogen ion concentration. Temp $=17{ }^{\circ} \mathrm{C},\left[\mathrm{Cr}\right.$ (III)-DTPA] $=2 \times 10^{-4} \mathrm{~mol} \mathrm{dm}^{-3}$, a-short reaction time, b-long reaction time.

In the oxidation of Cr(III)NTMP (NTMP nitrilotris (methylenephosphonic acid) by periodate ${ }^{[7]}$, the rate constant was equal $0.236 \mathrm{~mol}^{-1} \mathrm{dm}^{3} \mathrm{~s}^{-1}$ at $25^{\circ} \mathrm{C}$ and $\mathrm{pH}=$ 6.75 comparing to a value of $1.64 \mathrm{~mol}^{-1} \mathrm{dm}^{3} \mathrm{~s}^{-1}$ at $22^{\circ} \mathrm{C}$ and $\mathrm{pH}=6.7$ for the present study. The higher value for the reaction of $\mathrm{Cr}$ (III)DTPA complex with periodate than that for $\mathrm{Cr}(\mathrm{III}) \mathrm{NTMP}$ complex was due to:

i- the lower negative charge of the Cr(III)DTPA (-1) than that for Cr(III)NTMP(-3).

ii- the bulkiness of the tetrahedral phosphonate groups compared to the planer carboxylate which retards the reaction rate.

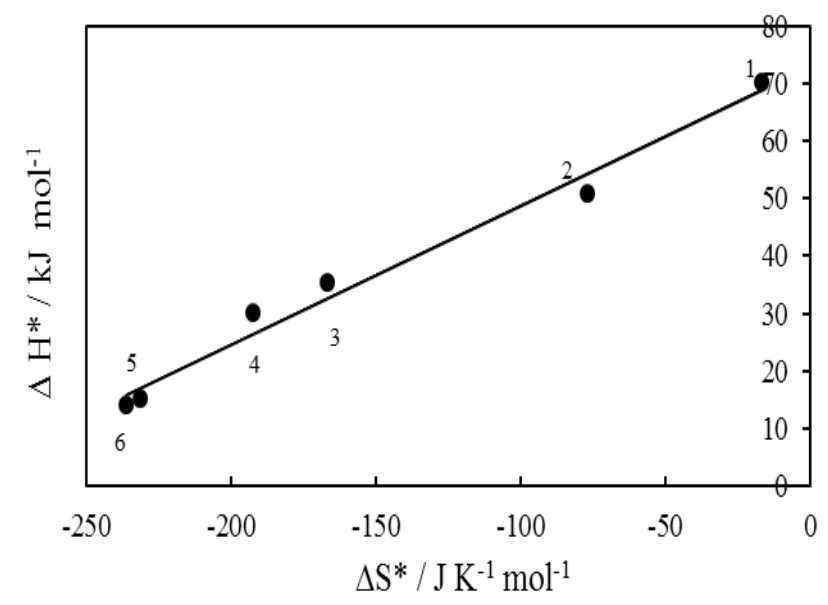

Fig. 9: Isokinetic plot for oxidation of chromium(III)-complexes by periodate, $(1,2)$ this work, (3) ${ }^{[9]},(4){ }^{[4]},(5)^{[6]},(6)^{[8]}$.

\section{Conclusion}

The oxidation of diethylenetriaminepentaacetato chromium (III), (Cr(III)-DTPA), by periodate is assigned an inner-sphere mechanism. A common mechanism for the oxidation of $(\mathrm{Cr}$ (III)-DTPA by periodate is proposed and is supported by the excellent isokinetic relationship between $\Delta \mathrm{H}^{*}$ and $\Delta \mathrm{S}^{*}$ for oxidation of hydroxochromium(III) complexes by periodate indicates that they follow the same mechanism.

\section{References}

1) Hussein, M.A., Abdel-Khalek, A.A. and Sulfab, Y. (1983). Inner-Sphere oxidation of Diaqua (nitrilotriacetato)cobaltate(II) by periodate in acetate medium. Isokinetic relationship for the oxidation of (Aminopolycarboxylate)cobalt(II) complexes by periodate. J. Chem. Soc. Dalton Trans. 317-321.

2) Al-Jallal, N.A. and Sulfab, Y. (1981). Kinetics of the oxidation of aquaethylenediaminetetraacetatochromium(III) by periodate. Trans. Met. Chem. 8: 51-53.

3) Guardado, P., Maestre, A. and Balon, M. (1981). Kinetics and salt effects on the reaction between octacyanotungstate(IV) and periodate ions. J. Inorg. Nucl. Chem. 43(6): 1391-1393.

4) Kasim, A.Y. and Sulfab, Y. (1981). Kinetics and mechanisms of chromium(III)-periodate reaction. Inorg. Chem. 20: 506-509.

5) Abdel-Khalek, A.A., Sayyah, E.M. and Ewais, H.A. (1997). Kinetics and mechanism of oxidation of chromium(III)-l-arginine complex by periodate. Trans. Met. Chem. 22(6): 557-560. 
6) Abdel-Hady, A. M. (2000). Kinetics of oxidation of a 2-aminomethylpyridinechromium(III) complex by periodate. Trans. Met. Chem. 25(4): 437-442.

7) Anis, S.S., Mansour, M.A. (2001). Kinetics and mechanism of the oxidation of nitrilotris (methylenephosphonato)chromium(III) periodate. Trans. Met. Chem. 26(6): 695-699.

8) Sulfab, Y. and Al-Jallal, N.A. (2004). Inner-sphere oxidation of cis-diaqua(oxalato)chromate(III) by periodate in weakly aqueous acidic solutions. Trans. Met. Chem. 29: 216-220.

9) Ewais, H.A., Dahman, F.D. and Abdel-Khalek, A.A. (2009). Inner-sphere oxidation of ternary iminodiacetatochromium(III) complexes involving DL-valine and L-arginine as secondary ligands. Isokinetic relationship for the oxidation of ternary iminodiacetato-chromium(III) complexes by periodate. Chem. Central J. 3: 3 .

10) Ali, I.H. and Sulfab, Y. (2011). One-step, twoelectron oxidation of cis-diaquabis $(1,10-$ phenanthroline)chromium(III) to cis-dioxobis $(1,10$ phenanthroline)chromium $(\mathrm{V})$ by periodate in aqueous acidic solutions. Int. J. Chem. Kinet. 43(10): 563-568.

11) Ali, I.H. and Sulfab, Y. (2013). Kinetics and mechanism of oxidation of cis-diaquabis (glycinato)chromium(III) by periodate ion in aqueous solutions. Trans. Met. Chem. 38(1): 79-84.

12) Ali, I.H. and Sulfab, Y. (2012). Concurrent two one-electron transfer in the oxidation of chromium(III) complexes with trans-1,2diaminocyclohexane- $N, N, N^{\prime}, N^{\prime}$-tetraacetate and diethylenetriaminepentaacetate ligands by periodate ion. Int. J. Chem. Kinet. 44(11): 729-735.

13) Bucci, R., Magri, A.D., Magri, A.L. and Napoli, A. (2000). On the reaction of iron(III) with chromium(III)-DTPA chelating agent. Polyhedron 19: 2421-2425.

14) Thakur, P., Mathur, J.N., Moore, R.C. and Choppin, G.R. (2007). Thermodynamics and dissociation constants of carboxylic acids at high ionic strength and temperature. Inorg. Chim. Acta 360: 3671-3680.

15) Basolo, F. and Pearson, R.G. (1958). Mechanism of Inorganic Reactions: A Study of Metal Complexes in Solution. J. Wiley \& Sons (426 pages).

16) Sulfab, Y., Taylor, R.S. and Sykes, A.G. (1976). Rapid equilibration of ethylene-N,N,N',N'tetraacetato-aquochromate(III) complex with chromate(VI), molybdate(VI), tungestate(VI) and azide. Labilization of the aqua ligand by the free carboxylate and substitution at chromium(III). Inorg. Chem. 15: 2388-2393.

17) Ogino, H., Watanabe, T. and Tanaka, N. (1975). Equilibrium and kinetic studies of the reactions of $\mathrm{N}$ substituted ethylenediamine-N, $\mathrm{N}^{\prime}, \mathrm{N}^{\prime}$-triacetatoaqua chromium(III) with acetate ions. Inorg. Chem. 14(9): 2093-2097. 